\title{
Early Adolescents' Enjoyment Experienced in Learning Situations at School and Its Relation to Student Achievement
}

\author{
Gerda Hagenauer ${ }^{1} \&$ Tina Hascher ${ }^{2}$ \\ ${ }^{1}$ Department of Educational Research; Friedrich-Schiller-University, Jena, Germany \\ ${ }^{2}$ Department of Educational Research; Bern University, Bern, Switzerland \\ Correspondence: Gerda Hagenauer, Department of Educational Research; Friedrich-Schiller-University, Jena, Germany.
}

Received: October 25, 2013

Accepted: November 9, 2013 Online Published: January 24, 2014

doi:10.11114/jets.v2i2.254

URL: http://dx.doi.org/10.11114/jets.v2i2.254

\begin{abstract}
While many studies confirm that positive emotions, including enjoyment, lead to better student achievement, less empirical evidence exists about possible mediator variables that link achievement to enjoyment. It is proposed that achievement and enjoyment form a circular dependency; enjoyment in learning leads to higher achievement but a degree of achievement is required to enjoy learning. This study provides insight into the reverse of the much studied enjoyment to achievement link and provides practical recommendations on how to use these findings. Founded in Control-value theory, which suggests that control and value cognitions are important variables that mediate the connection between enjoyment and achievement, this study explores the reciprocal achievement-cognition-enjoyment link. The reciprocal link was investigated by applying a one year longitudinal design to students of grade 6 and $7(\mathrm{~N}=$ 356). This age group was chosen because early adolescence represents a critical period during which a strong decrease in positive learning emotions is observed. Part of the work involved identifying factors that might be responsible for this negative development. Results of cross-lagged path analysis identified reciprocal effects between student achievement and enjoyment with control and value cognitions functioning as partial mediators. High achievement goes with high control and value cognitions, which in turn positively affect enjoyment. However, cross-lagged correlations could only be partly confirmed. The results are discussed in terms of theoretical and practical implications
\end{abstract}

Keywords: enjoyment, achievement, control-value theory, early adolescence, academic emotions

\section{Introduction}

There is a substantial body of research on student motivation and its association to achievement, but far less exists on the link between emotions in the classroom and achievement (for an overview on learning and emotions, see Hascher 2010; Schutz and Pekrun 2007). Research into learning emotions received little attention for many years (Pekrun 1998) as studies concentrated mainly on text anxiety (e.g., Cassady and Johnson 2002).

This picture has changed as researchers became aware of the variety of emotional experiences in the classroom and the relevance of these experiences on students' learning and achievement. Subsequently, research into students' emotions in the classroom and in learning and achievement situations continues to grow (e.g., Pekrun et al. 2002b).

Current research reveals that not only negative but also positive emotions deserve closer attention because of their beneficial effects on learning and achievement (Fredrickson 2001; Pekrun et al. 2002a). Positive emotions decrease during the years of schooling with the most obvious drop during early adolescence (Hagenauer and Hascher 2010). One crucial and basic positive emotion is enjoyment (Izard 1999; Plutchik 1980; Zelenski and Larsen 2000). Enjoyment is frequently experienced in the classroom learning context (Pekrun 1998) and is important for students' willingness to participate in lifelong learning. Consequently, this paper focuses on students' enjoyment in classroom learning situations.

Furthermore, because of the decrease of positive emotions in general and enjoyment in particular, studies are required that identify factors that impact on that negative trend. Gaining knowledge about antecedents of students' enjoyment, particularly in early adolescence as critical age period, can support the development of intervention programs that aim to counteract the drop in enjoyment levels.

The purpose of this study was to identify such impacting factors by building on a popular theory in the field of academic emotions: control-value theory. Control-value theory will be outlined in the next paragraph. In short, the 
theory suggests that the link between students' achievement and enjoyment is not a direct one, but an indirect one mediated through control-value cognitions. Consequently, we aim to test the association between students' achievement and enjoyment taking control- and value cognitions as mediator variables into account. The present study is innovative in three ways: (1) Firstly, it does not only test how achievement and enjoyment are related, but in line with a cognitive approach to emotions it also accounts for the mediating role of cognitions. This allows us to explain underlying processes that are responsible for the association between achievement and enjoyment. (2) Secondly, in the analysis we treat achievement as the independent variable impacting students' enjoyment (achievement $\rightarrow$ enjoyment). Previous studies focused on the reverse association (enjoyment $\rightarrow$ achievement; e.g. Villavicencio and Bernardo 2012). (3) Thirdly, the study applies a longitudinal design (see also Goetz et al. 2004) which enables us to explore the change of enjoyment and its related factors during early adolescence and therefore does better in explaining the reciprocal influences between the mentioned variables as solely cross-sectional and correlational designs.

\subsection{Enjoyment and Its Association with Achievement}

According to Pekrun et al. (2002a) enjoyment is classified as one of various learning emotions occurring in learning environments. It is triggered when students are confronted with different learning tasks in school. Due to its activating nature (Watson and Tellegen 1985) it is accompanied by desirable learning behavior, such as the use of deeper learning strategies (Pekrun and Hofmann 1999), more stable and enduring effort (Gendolla 2003), higher self-regulation (Villavicencio and Bernardo, 1985) and higher engagement (Reschly et al. 2008) which, in turn, promote students' achievement.

Focusing on the enjoyment $\rightarrow$ achievement or achievement $\rightarrow$ enjoyment link prior research reveals a positive connection between these two constructs: Higher achievement is connected to higher enjoyment and vice versa. As already stated the achievement-enjoyment link is explored less frequently than the enjoyment-achievement link. Also reciprocal linkages between achievement and enjoyment are continually discussed but tested rarely due to the lack of longitudinal research.

Control-value theory (Pekrun 2000; 2006; 2009) provides a theoretical framework that describes the connection between student's achievement and enjoyment. It suggests an indirect relationship mediated by control- and value cognitions. The importance of control and value cognitions for eliciting enjoyment corresponds with cognitive approaches to emotion. For example, Ellsworth and Scherer (2003) state that an emotion develops from an evaluation (= appraisal) of an actual event (see also Reisenzein 2001). Depending on this evaluation, either positive or negative emotion will arise. The evaluation of the situation is thus responsible for different emotional experiences despite identical environmental conditions (Clore and Ortony 2008). It can be assumed that low and high achievers judge identical classroom conditions differently.

Control-value theory identifies two different cognitions as crucial in the evaluation of the learning environment: control and value cognitions (e.g., Ahmed et al. 2010 a; b; Frenzel et al. 2007). Students' achievement level influences control and value cognitions that have a final impact on students' emotional experiences. If students are high achievers, control beliefs are high (Goetz et al. 2008) and value cognitions are positive (Fend 1997) leading to positive achievement emotions. In turn, these emotions cause the positive learning behavior that induces high achievement. As a consequence feedback loops between students' emotions, control-value cognitions, learning behavior, and achievement can be assumed. Hence, low achievement is detrimental because it is connected to negative cognitions, negative emotions, and poor learning behavior which enforce failure. Furthermore, research not only stresses the importance of student-teacher interaction and high quality instructionfor the development of positive emotions and learning. It also describes how the social environment (e.g., parents and teachers) respondsto low achievers in a controlling and negative manner (Deci et al 1982; Skinner and Belmont 1993).

Therefore, low achievement can be identified as a risk factor for the experience of enjoyment during learning. According to Flammer and Alsaker (2002), low achievers try to maintain their positive scholastic identity by devaluating scholastic learning. Positive value cognitions pertaining to scholastic learning, as preconditions of students' positive learning emotions, worsen, and consequently enjoyment and motivation decrease. The so called "discounting effect" (Tesser and Campbell 1983) describes an outcome of continuous psychological disengagement and misidentification that negatively affects students' enjoyment. As a result, the differences between low achievers' and high achievers' enjoyment increases with successive school years (Jerusalem and Mittag 1999 for the time course of enjoyment in mathematics). In general, several authors have addressed the age of young adolescence - in particular grade 7 in German speaking countries (Eder 2007; Fend 1997) - as the critical period for a severe loss in autonomous learning motivation (Anderman and Maehr 1994), which is strongly connected to enjoyment (Bieg and Mittag 2009; Ryan and Connell 1989).

\subsection{The Present Study}

The primary objective of this study was to examine the relationship between early adolescents' scholastic achievement 
level and their enjoyment in the context of scholastic instruction through the lens of control-value theory. Keeping in mind that positive affective and motivational trait variables, such as enjoyment in school or intrinsic learning motivation (across situations and subjects), decrease when students' progress in their school career (see Stage-Environment Fit Theory, Eccles and Midgley 1989), it is of importance to investigate the antecedents of these factors in order to prevent students' from becoming alienated and detached from school and formal learning (Hascher and Hagenauer 2010). The enjoyment of learning is relevant to education because it supports positive attitudes towards learning in general, which also support the participation inLifelong Learning. Thus, learning should not only be enjoyed through external rewards (e.g., the experience of performance enjoyment because the learning results qualifies for a higher position on the job ladder), it should also be driven by the intrinsic and autonomic motivation which accompany high enjoyment.

In short, we tested whether control- and value cognitions mediate the association between achievement and enjoyment. Additionally we tested to what extent control-and value cognitions as well as the achievement level could explain the change in students' enjoyment between grades 6 and 7. The tested model is depicted in Figure 1.

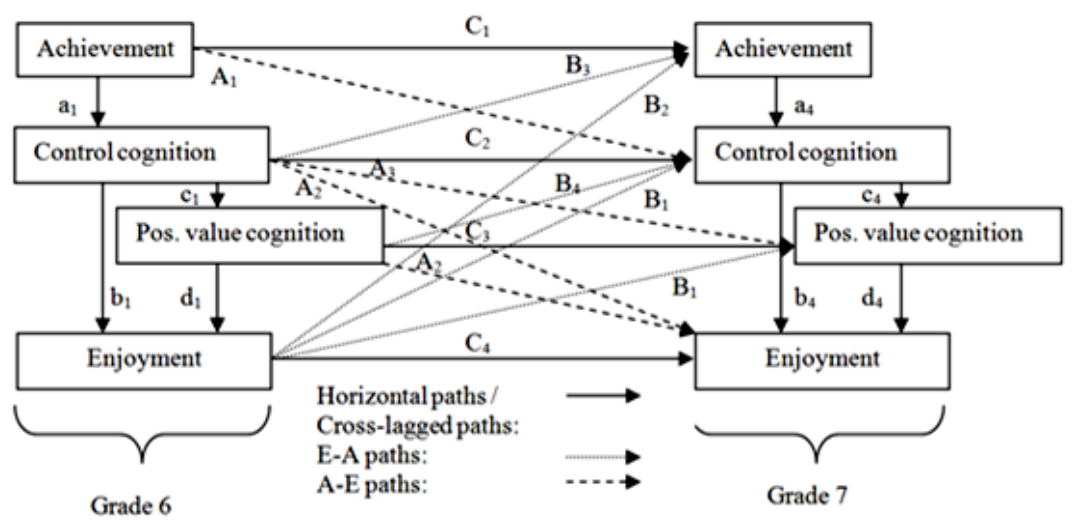

Figure 1. Conceptual model of the associations between achievement, control- and value cognitions, and students' enjoyment. All relations are expected to be positive.

On the one hand we aimed to test control-value theory cross-sectional within two measurement points, one in grade 6 and one in grade 7 . We assumed that high achievement follows high control cognitions $\left(a_{1 / 4}\right)$. If students feel secure about their learning ability ( $=$ high control cognition) their enjoyment is influenced positively $\left(b_{1 / 4}\right)$. As Scherer (2004) stated that appraisal processes function sequentially, we expected, based on Fends' findings (1997), that high control cognitions positively affect students' value cognitions $\left(c_{1 / 4}\right)$. If students think they can control the situation they also value the situation positively. On the other hand, if students frequently feel overstrained by the learning matter (= lack of control), the so called "discounting effect" (Flammer and Alsaker 2002) arises and students tend to devaluate school and learning. Thus, the theoretical basis of this model is formed by control-value theory and the "discounting effect". The "discounting effect" outlines the direction between control and value cognitions as follows. Low control cognitions lead to negative value cognitions. However, it should be kept in mind that interaction effects can exist between controland value cognitions (Goetz et al. 2010). Consequently, we hypothesized that value cognitions play a partially mediatory role between students' control cognitions and enjoyment $\left(d_{1 / 4}\right)$.

On the other hand, we investigated student development and tested control-value theory across two measurement points by calculating cross-lagged path analyses. Taking the reciprocity of the links between students' achievement, cognitions, and emotions into account we assumed "achievement-enjoyment effects" (A-E effects) as well as "enjoyment-achievement effects" (E-A effects). Thus, an "A-E path" indicates the effect of achievement on cognition $\left(A_{1}\right)$, and the effect of cognition on emotion $\left(A_{2}\right)$ as well as the effect of control cognition on value cognition $\left(A_{3}\right)$. "E-A paths" indicate the converse direction. Enjoyment influences cognition $\left(B_{1}\right)$ and achievement $\left(B_{2}\right)$ - the direct path of enjoyment achievement is also illustrated in Pekruns' model (2006). Control cognitions have an impact on students' achievement $\left(B_{3}\right)$, and value cognitions show a positive relationship with control cognitions $\left(B_{4}\right)$. Furthermore we hypothesized horizontal paths based on the relative stability of trait constructs $\left(C_{1 / 2 / 3 / 4}\right)$.

\section{Method}

\subsection{Sample - Design}

The sample consisted of 356 students ( $48.9 \%$ females, mean age at $\mathrm{t} 1=11.9$ years) within eight low track secondary schools (= "Hauptschule") $)^{1}$ located in urban and suburban areas of Austria. Paper-and-pencil questionnaires were administered to groups of students in their classrooms by trained staff members at four measurement points. Identical measures were collected at two points in time, 12.5 months apart, in March / April of consecutive school years (grades 
six and seven). To protect students from stress caused by research activities, intermediate measures t2 and t3 only included an assessment of the dependent variable (enjoyment) as well as some further open questions and scales that are not significant for the research question and analyses presented here.

\subsection{Variables}

\subsubsection{Enjoyment}

Enjoyment was measured using 13 items based on the multi-component approach to emotion and consists of 13 items. It integrates the affective (5 items, e.g., "I experience enjoyment while I'm learning."), the motivational (4 items, e.g., "I really want to learn many new things in school for myself."), and the cognitive (4 items, e.g., "I think learning is a good thing to do.") components as we were mainly interested in the students' psychological changes and experiences while enjoyment occurs (for a detailed description of a multicomponent approach to academic emotions, see Academic Emotion Questionnaire, Pekrun et al. 2011). Students were asked to express their degree of agreement or disagreement on a 4-point-Likert-scale $(1=$ not true at all, $4=$ true). The validity of the scale was tested by using exploratory and confirmatory factor analyses. Results of these analyses are reported elsewhere in detail (Hagenauer and Hascher 2011). In short, the factor analyses revealed a one-factor-structure for "enjoyment" with high internal consistency (Cronbach's $\left.\alpha_{11 / t 3 / t 4}=.93 ; \alpha_{12}=.94\right)$.

\subsubsection{Control- and Value Cognitions}

According to Pekruns' control-value theory (2006) control and value cognitions were assessed as mediators between achievement level and enjoyment.

The control-cognition "self-concept of ability" was derived from a scale developed by Rauer and Schuck (2003) for elementary school students and was adapted to lower secondary level. It shows satisfactory scale and item statistics (8 items, e.g., "I'm a good learner", Cronbach's $\alpha=.88$ at t1 and t4).

Based on the "discounting effect" the value cognition represents a negative value cognition and is denoted as "lack of subjective relevance to school" (Fend 1997). If the discounting effect occurs, students evaluate school and learning as senseless and score high on this scale. The scale was newly developed for the present study ( 5 items, e.g., "School learning is really senseless for me and my future", Cronbach's $\alpha_{t 1} \geq .88, \alpha_{t 4}=.90$ at t1 and t4). It assesses an intrinsic and identified value cognition (see Self-Determination Theory, Deci and Ryan 2002). Learning is evaluated positively for the learner and his / her interests (= intrinsic value cognition), but also with regard to the future of the learner (= identified value cognition) (for the distinction "intrinsic and extrinsic" value cognitions, see Pekrun 2006). For a better understanding this scale was inverted. Consequently, a high score on this scale reflects high positive value cognitions. The inverted scale is called "meaningfulness of school and scholastic learning".

The self-concept of ability was measured on a 4-point Likert scale ( $1=$ not true at all, $4=$ true $)$, the value cognition on a 6-point Likert scale $(1=$ never; 6 = very often $)$.

\subsubsection{Achievement Level}

Students' achievement in school was recorded on the basis of their grades in Mathematics, English and German (= "main subjects") in the school report of the preceding school term. The indicated achievement level is the average of the three grades (GPA). Cronbach's alpha for the achievement score is satisfactory for t1 (.65) and high for t4 (.89). Basically, the school grades in Austria vary from 1 to 5. Students who get a "1" (= "very good") in a subject area are high achievers, while "5" (= "insufficient") indicates low achievement. Grades, however, are not the only indicator for achievement in Austrian low track schools because of additional ability grouping. In the three main subjects (Mathematics, German, and the first second language, usually English), the students of a classroom are divided into three groups according to their ability level and potential. Higher achievers are placed in ability level 1 (= highest performance / achievement), while low achievers are grouped into ability level 3. Although the curriculum for all three groups is equal, academic demands differ. Within the groups grading is dependent on in-group achievement variation. As a consequence it is necessary to make the grades comparable because the same grade carries different information across the different ability groups. For students in ability level 2 , the value " 2 " has to be added to the received grade, while the value " 4 " is added to grades in ability group 3. After this adjustment grades range from 1 to $9(1=$ highest achievement; $9=$ lowest achievement). It is common to use this procedure if researchers want to account for the ability grouping in students' achievement (Eder 2007). It does not make sense to only use ability grouping as a variable for analyzing the association between achievements and enjoyment because the variance in achievement also varies between the students of the same ability level. Students receive grades from 1 to 5 within the same ability group; consequently students cannot be directly compared using the ability group as the only grouping variable. It is necessary, as reported above, to combine both the ability level and the grades. Finally, the GPA is recoded meaning that a high score equals high achievement in school $(1=$ lowest achievement; $9=$ highest achievement $)$. GPA in the three subjects 
Mathematics, English, and German is indicative because of its crucial importance for students' academic careers, academic self-concept, and academic emotions, e.g., student tracking is based on their grades in these three subjects. If students want to move to a high track school they have to have good grades in the three main subjects otherwise they are not allowed to attend schools with higher academic demands. Consequently, the main subjects are the most important emotion eliciting subjects and do affect students' enjoyment (Hagenauer 2011). If students' think that they cannot control their achievement in these subjects, it is likely that they start devaluating learning and enjoyment can hardly occur (see control-value theory, Pekrun 2000).

\section{Results}

\subsection{Descriptive Statistics and Correlations}

Enjoyment, achievement level as well as control and value cognitions are significantly higher in grade 6 compared to grade 7 which supports the decrease of enjoyment during early adolescence (for a detailed analyses of the development of these factors, see Hagenauer and Hascher 2010). All constructs are correlated positively. High achievement goes with high control and value cognitions, and with high enjoyment. Furthermore, constructs were positively correlated on a medium level between grade 6 and 7. The correlation of achievement level in grade 6 and 7 was high (see Table 1).

Table 1.Mean, standard deviation, and intercorrelations

\begin{tabular}{|c|c|c|c|c|c|c|c|c|c|c|c|}
\hline & & \multirow[t]{2}{*}{$M$} & \multirow[t]{2}{*}{ SD } & \multicolumn{8}{|c|}{ Correlation coefficient (Pearson) } \\
\hline & & & & $(1)$ & $(2)$ & (3) & (4) & $(5)$ & $(6)$ & (7) & $(8)$ \\
\hline (1) & GPA 1 & 5.80 & 1.62 & - & & & & & & & \\
\hline (2) & $\mathrm{CC} 1$ & 3.00 & 0.64 & $.50 * * *$ & - & & & & & & \\
\hline (3) & $\mathrm{VC} 1$ & 4.98 & 1.19 & $.21 * * *$ & $.48 * * *$ & - & & & & & \\
\hline (4) & EJ 1 & 2.52 & 0.73 & .11 & $.51 * * *$ & $.59 * * *$ & - & & & & \\
\hline$(5)$ & GPA 4 & 5.70 & 1.74 & $.89 * * *$ & $.48 * * *$ & $.28 * * *$ & $.17 * *$ & - & & & \\
\hline (6) & $\mathrm{CC} 4$ & 2.95 & 0.63 & $.37 * * *$ & $.61 * * *$ & $.42 * * *$ & $.40 * * *$ & $.47 * * *$ & - & & \\
\hline (7) & VC 4 & 4.68 & 1.30 & $.17 * *$ & $.35 * * *$ & $.46 * * *$ & $.39 * * *$ & $.19 * * *$ & $.44 * * *$ & - & \\
\hline (8) & EJ 4 & 2.33 & 0.70 & .06 & $.33 * * *$ & $.41 * * *$ & $.60 * * *$ & $.14 * *$ & $.55 * * *$ & $.55 * * *$ & - \\
\hline
\end{tabular}

Note. GPA 1/GPA 4: Achievement at $\mathrm{t} 1$ and $\mathrm{t} 4$; CC 1 / CC 4: Self-concept of ability as indicator of a trait control cognition at $\mathrm{t} 1$ and $\mathrm{t} 4(1=\min ; 4=\max ) ; V C 1 / V C 4$ : Meaningfulness of school and academic learning as indicator of a positive value cognition at $\mathrm{t} 1$ and $\mathrm{t} 4(1=\min ; 6=\max ) ; E J 1 / E J 4$ : Enjoyment at $\mathrm{t} 1$ and $\mathrm{t} 4(1=\min ; 4=\max ) ;{ }^{* * *} \mathrm{p}$ $<.001 ; * * \mathrm{p}<.01$

\subsection{Associations between Students'Achievement, Cognitions, and Enjoyment}

In order to examine the hypothesized model depicted in Figure 1 we competitively tested four different nested models by means of manifest path analyses using the mean score of each described scale as independent, intermediate and dependent (manifest) variables (see Goetz et al. 2006b). The statistical software Mplus (Muthén and Muthén 1998-2009) was applied in order to calculate the path models. Missing data were estimated by FIML (Allison 2003). Accounting for the nested nature of the data (students in classes) the standard errors were adjusted for (Type $=$ complex). An alpha level of .05 was used for all statistical tests.

In model A we specified paths within one measurement point $\left(\mathrm{a}-\mathrm{d}_{1-4}\right)$, as well as the horizontal effects between measurement points 1 and 4 , to test the stability of the constructs between grades 6 and $7\left(\mathrm{C}_{1}-\mathrm{C}_{4}\right)$. These horizontal effects were retained in the other models to control for stability. Additionally, the cross-sectional paths within the measurement point were retained. In model B, Enjoyment-Achievement effects $(A-E)$ were central $\left(\mathrm{a}-\mathrm{d}_{1-4} ; \mathrm{C}_{1}-\mathrm{C}_{4}+\mathrm{A}_{1}-\mathrm{A}_{3}\right)$. Model $\mathrm{C}$ represents Achievement-Enjoyment effects $(E-A)\left(\mathrm{a}-\mathrm{d}_{1-4} ; \mathrm{C}_{1}-\mathrm{C}_{4}+\mathrm{B}_{1}-\mathrm{B}_{4}\right)$. In model $\mathrm{D}$ reciprocal effects (cross-lagged; a-d $\mathrm{d}_{1-4} ; \mathrm{C}_{1}-\mathrm{C}_{4}+\mathrm{A}_{1}-\mathrm{A}_{3}+\mathrm{B}_{1}-\mathrm{B}_{4}$ ) were specified. Because of the strong interplay of emotions, cognitions, and achievement, we expected the best fit for model $\mathrm{D}$.

The model fits are shown in Table 2. Model B, with integrated E-A effects, shows a significant gain of fit compared to Model A, which only presents horizontal effects $\left(\Delta \chi^{2}=34.35 ; \Delta \mathrm{df}=6 ; \mathrm{p}<.01\right)$. While model $\mathrm{C}$, which is specified by additional A-E effects, shows a significantly better fit than model $\mathrm{A}\left(\Delta \chi^{2}=17.89 ; \Delta \mathrm{df}=4 ; \mathrm{p}<.01\right)$, it shows a significantly weaker fit than model $\mathrm{B}\left(\Delta \chi^{2}=16.46 ; \Delta \mathrm{df}=2 ; \mathrm{p}<.01\right)$. In the reciprocal model $\mathrm{D}$ the model fit is ample and shows significantly better fits than models $\mathrm{A}, \mathrm{B}$ and $\mathrm{C}$. 
Table 2. Results of four competitive models

\begin{tabular}{llllllll}
\hline Models & $\chi^{2}$ & $\mathrm{df}$ & $\chi^{2} / \mathrm{df}$ & CFI & TLI & RMSEA & SRMR \\
\hline A & 61.34 & 16 & 3.83 & .95 & .91 & .09 & .06 \\
B & 26.99 & 10 & 2.70 & .98 & .95 & .07 & .04 \\
C & 43.45 & 12 & 3.62 & .96 & .92 & .09 & .05 \\
D & 13.74 & 7 & 1.96 & .99 & .97 & .05 & .03 \\
\hline
\end{tabular}

Note.Model A: Paths within one measurement point and horizontal effects between the measurement points were specified; Model B: adding Enjoyment-Achievement Effects (E-A); Model C: adding Achievement-Enjoyment Effects (A-E); Model D: E-A and A-E effects (reciprocal effects).

As expected model D is the preferred model although not all expected paths are significant (see Figure 3; standardized Beta-coefficients are shown).

Looking at the cross-sectional paths at $\mathrm{t} 1$ and $\mathrm{t} 4$, high achievement is positively related to high control cognitions $\left(\beta_{\mathrm{t} 1}\right.$ $\left.=.45 ; \beta_{\mathrm{t} 4}=.29\right)$, which, in turn, is positively correlated with positive value cognitions $\left(\beta_{\mathrm{t} 1}=.40 ; \beta_{\mathrm{t} 4}=.24\right)$ as well as enjoyment $\left(\beta_{\mathrm{t} 1}=.22 ; \beta_{\mathrm{t} 4}=.31\right)$. Students' value cognitions are also positively associated with students' enjoyment $\left(\beta_{\mathrm{t} 1}\right.$ $\left.=.48 ; \beta_{\mathrm{t} 4}=.28\right)$, and function as partially mediatory variables between students' control cognition and enjoyment. The path model which does not account for the direct effect of students' control cognitions on enjoyment shows a significant weaker data fit $\left(\chi^{2}[9]=66.02 ; \mathrm{df}=9 ; \mathrm{CFI}=.93 ; \mathrm{TLI}=.80 ; \mathrm{RMSEA}=.13 ; \mathrm{SRMR}=.05\right)$. Also, the model regarding control- and value cognitions as parallel predictors reveals a weak model fit $\left(\chi^{2}[8]=45.02 ; \mathrm{CFI}=.96\right.$; TLI $=.85$; RMSEA = .11; SRMR = .04). Consequently, the associations expected between the variables have been confirmed.

Regarding the cross-lagged paths, only a few associations could be observed. Students' ability-concept in grade 6 shows a positive association with students' value cognition $(\beta=.25)$ and enjoyment $(\beta=-.19)$ in grade 7 . The negative path coefficient between students' ability concept (t1) and enjoyment (t4) indicates an unexpected result: the higher students' control cognitions in grade 6, the greater the loss of enjoyment between grades 6 and 7 . Descriptive data confirm these results. Although high achievers (percentile 25 of the GPA of grade $6(\mathrm{t} 1), \mathrm{n}=103$ ) show a greater extent of enjoyment at both measurement points compared to low achievers (percentile 75 of the GPA of grade $6(t 1)$, $n=99)$, the decrease in enjoyment, is stronger for high achievers as it is reflected by conducted dependent $t$-tests and by calculated effect sizes for the change of enjoyment for both student groups (high achievers: $M_{\mathrm{t} 1}=2.63(S D=0.74) ; M_{\mathrm{t} 4}=2.39(S D=$ $0.72) ; d=0.34$; low achievers: $\left.M_{\mathrm{t} 1}=2.46(S D=0.77) ; M_{\mathrm{t} 4}=2.32(S D=0.72) ; d=0.18\right)$. Other significant paths reveal additional links between students' enjoyment in grade 6 and control-cognitions $(\beta=.28)$ as well as achievement level $(\beta$ $=.08$ ) in grade 7 . High enjoyment in grade 6 supports students' control cognitions and achievement in grade 7 . All other cross-lagged paths are not significant (see Figure 2).

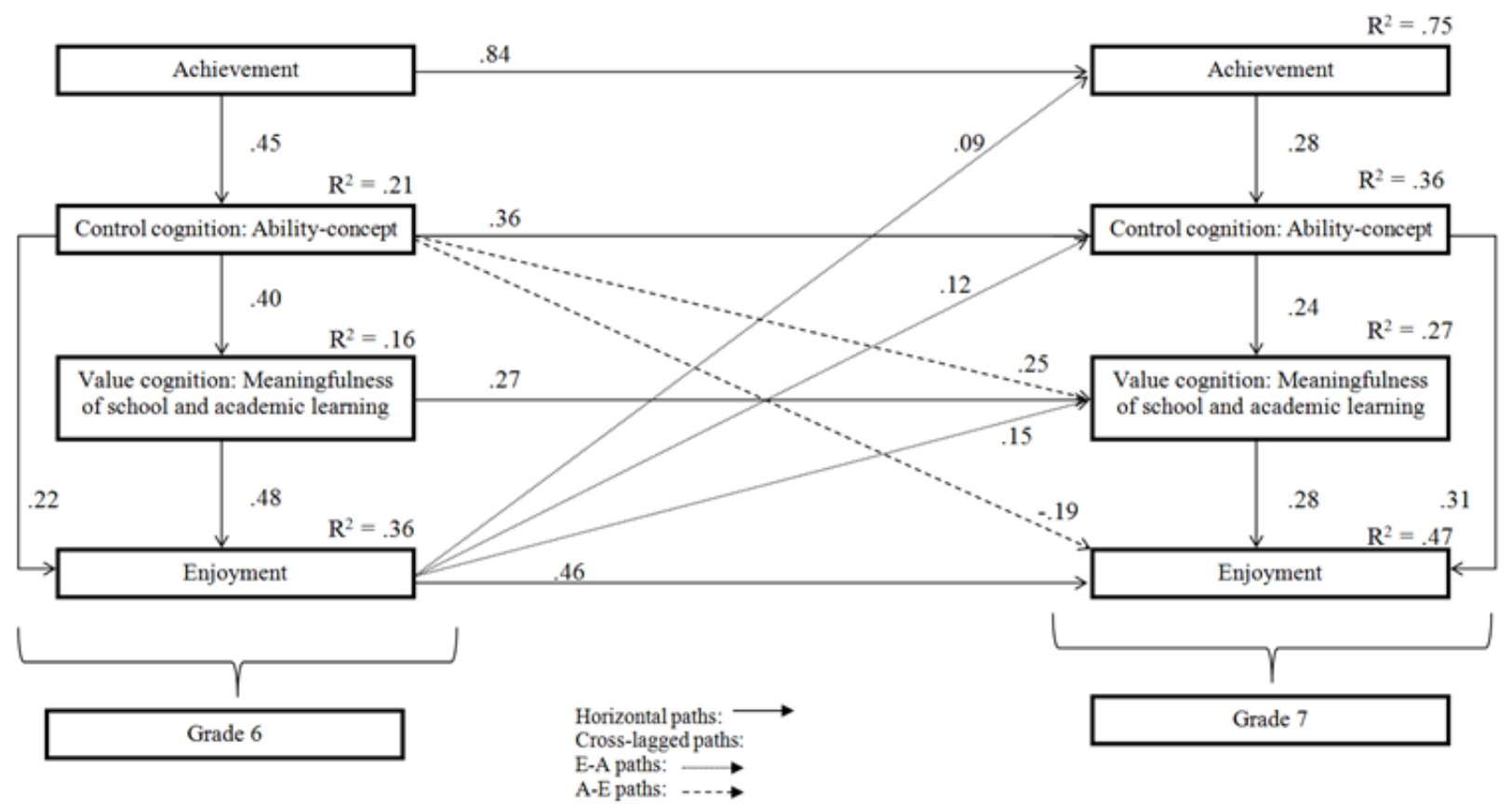

Figure 2. Standardized path coefficients for the model predicting relations between students' achievement, control- and value cognitions, and enjoyment between grades 6 and 7 . 


\section{Discussion}

The purpose of the study was to examine the association between student achievement level, control and value cognitions, and enjoyment during a period of time that is critical for their positive emotions in school (Anderman and Maehr 1994; Fend 1997; Harter 1996). To do this, we undertook a longitudinal study of students from grade 6 to 7 (= early adolescence), and applied questionnaires at various points.

First, the results indicate differences between grades 6 and 7 in terms of enjoyment. As students' progress in school their enjoyment decreases, which confirms the idea of grade 7 as a critical period for a positive scholastic development (Hagenauer and Hascher 2010). The results also point to the need to pay more attention to previous grades as a negative development may have an earlier origin.

Second, the results confirm the positive impact of student achievement on control cognitions, which in turn positively influence value cognitions and enjoyment.

Third, consistent with control-value theory (Pekrun 2006; 2009), we confirmed the mediating role of control and value cognitions on the relationship between achievement and enjoyment. We also found evidence for reciprocal linkages between the variables across measurement points. One result confirmed the direct relationship between students' enjoyment in grade 6 and students' achievement in grade 7. Subsequently, positive emotions do not only have an indirect influence on students' achievement level but also have a direct, beneficial effect. This counts for a specific teacher investment in fostering positive emotions. A strong relationship between students' control cognitions and enjoyment across the measurement points is also noticeable; whereas, the linkage between students' value cognitions and enjoyment is not as strong (see Boekaerts 2007). As a consequence, instruction should be designed as emotionally and cognitively supportive (for an example of an emotionally supportive instructional style in science, see Astleitner 2000; Gläser-Zikuda et al. 2005). It is necessary that both emotions and cognitions are fostered in school in order to facilitate achievement, as a strong interplay can be assumed.

However, limited support was found for other cross-lagged paths; for example, the path between control cognitions in grade 6 and achievement in grade 7. We predicted that high control cognitions in grade 6 would influence subsequent achievement level in grade 7 . The high stability of achievement over time may has contributed to this result, as achievement in grade 6 correlated strongly (.84) with achievement in grade 7. From a practical point of view, the stability of achievement requires an early intervention in terms of preventing low achievement and thus, reducing negative side-effects, such as negative emotions and detachment from school.

Why students' with higher control cognitions in grade 6 lose a greater amount of enjoyment between grades 6 and 7 compared to students with lower control cognitions currently remains an open question and needs further research. One explanation is that those who own more are at risk to lose more (Hagenauer and Hascher 2011). Grades drop independent of students' achievement level in secondary schools compared to primary schools. High achievers may suffer more extensively from a perceived decrease in competence beliefs as they were used to being successful most of the time in previous years. It is also possible that during grade 7 these students are more aware that their achievement level is only partly in their control (= lower control cognitions) which leads to the observed reduction of enjoyment.

Despite sound findings on achievement, students' cognitions, and enjoyment, some limitations of the current study have to be taken into account.

One limitation concerns the assessment of achievement levels. For the GPA we used the students' grades in Mathematics, German, and English as they are most relevant to students' school careers. Good grades in these subjects are a precondition for a successful transition to upper secondary level. However, this procedure neglects the fact that students build their academic self-concept and learner identity not only upon main subjects but also upon grades in the subsidiary subjects (e.g., history, biology, and physical education). Achievement in these subjects might also be powerful for emotional experiences in school. Thus, it will be an issue of future studies to integrate grades of different subject areas in the GPA in order to receive a more elaborate indicator of students' achievement level at school. It would also be of interest to compare a GPA composed of students' grades in school with a GPA indicator based on an independent achievement test as done in studies like TIMSS or PISA. These two achievement indicators could be explored in terms of their relevance for predicting students' enjoyment. Further, there is a need to assess both domain-specific GPAs and domain-transcending GPAs and investigate the association with domain specific enjoyment and domain transcending enjoyment concurrently (Goetz at al. 2006a).

Second, causality must not be drawn from these results. As already stated, the model only includes selected variables (relying on control-value theory, see Pekrun, 2006), and does not provide a complete picture of the variables that may influence enjoyment. Future studies should extend the tested model and account for additional variables (for example, assessing more different cognitions), as well as include context variables. Alongside testing more complex models on an 
inter-individual level with consideration of the context, person-centred analyses are also required. For example, Ahmed, van der Werf, Minnaert, and Kuyper (2010b) have shown that variance in emotional experiences can be explained by differences across students, but that an amount of variance is also explained by intra-individual variability in emotional experiences across days.

Third, in our research we focused on domain-transcending enjoyment although there is also empirical evidence that enjoyment can be arranged domain-specifically (Goetz et al. 2006a; Goetz et al. 2010). We justify the domain-transcending focus by arguing that enjoyment across subject areas is important for taking part in lifelong learning (Lüftenegger et al. 2012), which is an explicit goal of the OECD. It is important that learners develop generalized, positive emotional and motivational attitudes towards institutionalized learning. Consequently, it is of relevance that students, and adolescent learners in particular, experience enjoyment in general when they are confronted with new learning matters and the development of alienation from school and learning should be prevented (Hascher \& Hagenauer, 2010). We assume that domain transcending learning enjoyment is a necessary precondition for learners' stable and enduring interest in lifelong learning and that it is of particular relevance to maintain this domain-transcending learning enjoyment. However, due to the chosen domain-transcending focus some associations between the constructs in the present study might have been underestimated.

Despite these limitations, the findings of the study allow to draw implications for theory and practice. Theoretically, the results confirm the relevance of students' achievement on student's control- and value cognitions and enjoyment. Hence, control-value theory could be depicted within one measurement point but not entirely across measurement points. Future studies should extend the tested models as suggested above, e.g. by accounting for cognitions beyond control-and value cognitions and by adding motivational and cognitive learning variables as outcome of enjoyment alongside achievement (e.g., self-regulation, learning strategies). From a practical perspective, the results underpin the interplay of achievement, cognitions, and emotions. If teachers aim to foster students' positive emotional experiences within the critical age period of early adolescence, they have to apply intervention strategies that promote students' control and value cognitions as well as their achievement. Success in school within a student's own performance spectrum should be reachable as it enhances competence and value beliefs and, in turn, enjoyment. By providing an appropriate learning environment (e.g., offering continuous feedback; providing tasks based on different competence levels; allowing collaborative learning, clarification the value of particular learning topics for students' daily life) schools as institutions as well as teachers can support young adolescents' experiences of enjoyment in learning situations.

\section{References}

Ahmed, W., Minnaert, A., van der Werf, G., \& Kuyper, H. (2010a). The role of competence and value beliefs in students' daily emotional experiences: A multilevel test of a transactional model. Learning and Individual Differences, 20, 507-511. http://dx.doi.org/10.1016/j.lindif.2010.03.005.

Ahmed, W., van der Werf, G., Minnaert, A., \& Kyper, H. (2010b). Students' daily emotions in the classroom: intra-individual variability and appraisal correlates. British Journal of Educational Psychology, 80, 583-597. http://dx.doi.org/10.1348/000709910X498544

Allison, P. D. (2003). Missing data techniques for structural equation modeling. Journal of Abnormal Psychology, 112, 545-557. http://dx.doi.org/10.1037/0021-843X.112.4.545.

Anderman, E. M., \& Maehr, M. L. (1994). Motivation and schooling in the middle grades. Review of Educational Research, 64(2), 287-309. http://dx.doi.org/10.3102/00346543064002287.

Astleitner, H. (2000). Designing emotionally sound instruction: The FEASP-approach. Instructional Science, 28, 169-198. http://dx.doi.org/10.1023/A:1003893915778.

Bieg, S., \& Mittag, W. (2009). Die Bedeutung von Unterrichtsmerkmalen und Unterrichtsemotionen für die selbstbestimmte Lernmotivation [The relevance of instructional characteristics and learning emotions on self-determined learning motivation]. Empirische Pädagogik, 23(2), 117-142.

Boekaerts, M. (2007). Understanding students' affective processes in the classroom. In P. A. Schutz \& R. Pekrun (Eds.), Emotion in Education (pp. 37-56). Amsterdam: Elsevier.

Cassady, J. C., \& Johnson, R. E. (2002). Cognitive Test Anxiety and Academic Performance. Contemporary Educational Psychology, 27, 270-295. http://dx.doi.org/10.1006/ceps.2001.1094.

Clore, G. L., \& Ortony, A. (2008). Appraisal Theories. How cognition shapes affect into emotion. In M. Lewis, J. M. Haviland-Jones, \& L. Feldman Barrett (Eds.), Handbook of Emotions ( $3^{\text {rd }}$ edition, pp. 628-642). New York \& London: Guilford Press. 
Deci, E. L., \& Ryan, R. M. (2002) (Eds.). Handbook of Self-Determination Research.Rochester, N.Y.: University of Rochester Press.

Deci, E. L., Spiegel, N. H., Ryan, R. M., Koestner, R., \& Kauffmann, M. (1982). The effects of performance standards on teaching styles: The behavior of controlling teachers. Journal of Educational Psychology, 74(6), 852-859. http://dx.doi.org/10.1037/0022-0663.74.6.852.

Eccles, J. S., \& Midgley, C. (1989). Stage-Environment-Fit: Developmentally appropriate classrooms for young adolescents. In C. Ames, \& R. Ames (Eds.), Research on Motivation and Education. Goals and Cognitions (Volume 3, pp. 139-186). San Diego: Academic Press.

Eder, F. (2007). Das Befinden von Kindern und Jugendlichen in der österreichischen Schule [Student well-being in Austrian schools]. Innsbruck: Studienverlag.

Ellsworth, P. C., \& Scherer, K. R. (2003). Appraisal Processes in emotion. In R. J. Davidson, K. R. Scherer, \& H. Hill Goldsmith (Eds.), Handbook of affective sciences (pp. 572-595). Oxford: University Press.

Fend, H. (1997). Der Umgang mit Schule in der Adoleszenz [Coping with school during adolescence]. Bern: Huber.

Flammer, A., \& Alsaker, F. D. (2002). Entwicklungspsychologie der Adoleszenz. Die Erschließung innerer und äußerer Welten im Jugendalter [Developmental psychology of adolescence]. Bern: Hans Huber.

Fredrickson, B. L. (2001). The role of positive emotions in positive psychology: The broaden-and-build theory of positive emotions. American Psychologist, 56(3), 218-226.

Frenzel, A. C., Pekrun, R., \& Goetz, T. (2007). Girls and mathematics - A "hopeless" issue? A control-value approach to gender differences in emotions towards mathematics. European Journal of Psychology of Education, 26, 497-514. Http://dx.doi.org/10.1007/BF03173468.

Gendolla, G. H. E. (2003). Mood effects and effort mobilisation in learning: Theory and experimental evidence. In Ph. Mayring, \& Ch. von Rhoeneck (Eds.), Learning emotions. The influence of affective factors on classroom learning (pp. 29-46). Frankfurt: Peter Lang.

Gläser-Zikuda, M., Fuß, St., Laukenmann, M., Metz, K., \& Randler, Ch. (2005). Promoting students' emotions and achievement - Instructional design and evaluation of the ECOLE-approach. Learning and Instruction, 15(5), 481-495. http://dx.doi.org/10.1016/j.learninstruc.2005.07.013.

Goetz, T., Cronjäger, H., Frenzel, A. C., Lüdtke, O., \& Hall, N. C. (2010). Academic self-concept and emotion relations: Domain specificity and age effects. Contemporary Educational Psychology, 35, 44-58. http://dx.doi.org/10.1016/j.cedpsych.2009.10.001.

Goetz, T., Frenzel, A., Hall, N.,\& Pekrun, R. (2008). Antecedents of academic emotions: Testing the internal/external frame of reference model for academic enjoyment. Contemporary Educational Psychology, 33(1),9-33. http://dx.doi.org/10.1016/j.cedpsych.2006.12.002.

Goetz, T., Frenzel, A., Pekrun, R., \& Hall, N. (2006). The domain specificity of academic emotional experiences. The Journal of Experimental Education, 75(1), 5-29. http://dx.doi.org/10.3200/JEXE.75.1.5-29.

Goetz, T., Hall, N., Frenzel, A. C., \& Pekrun, R. (2006). A hierarchical conceptualization of enjoyment in students. Learning and Instruction, 16, 323-338. http://dx.doi.org/10.1016/j.learninstruc.2006.07.004.

Goetz, T., Pekrun, R., Zirngibl, A., Jullien, S., Kleine, M., Vom Hofe, M., \& Blum, W. (2004). Leistung und emotionales Erleben im Fach Mathematik. Längsschnittliche Mehrebenenanalyse [Achievement and emotional experiences in maths. Longitudinal multi-level analysis.]. Zeitschrift für Pädagogische Psychologie, 18(3/4), 201-212. http://dx.doi.org/10.1024/1010-0652.18.34.20.

Hagenauer, G., \& Hascher, T. (2010). Learning Enjoyment in Early Adolescence. Educational Research and Evaluation, 16(6), 495-516.http://dx.doi.org/10.1080/13803611.2010.550499.

Hagenauer, G., \& Hascher, T. (2011). Schulische Lernfreude in der Sekundarstufe 1 und deren Beziehung zu Kontrollund Valenzkognitionen [Learning Enjoyment at the Lower Secondary Level and Its Association with Control and Valence Cognitions]. Zeitschrift für Pädagogische Psychologie, 25(1), 63-80.http://dx.doi.org/10.1024/1010-0652/a000026.

Harter, S. (1996). Teacher and classmate influences on scholastic motivation, self-esteem, and level of voice in adolescence. In J. Juvonen \& K. R. Wentzel (Eds.), Social Motivation. Understanding children's school adjustment (pp. 11-42). Cambridge (US): Cambridge University Press.

Hascher, T. (2010). Learning and Emotion: perspectives for theory and research. European Educational Research 
Journal, 9, 13-28.

Hascher, T., \& Hagenauer, G. (2010). Alienation from School. International Journal of Educational Research, 49(6), 220-232. http://dx.doi.org/10.1016/j.ijer.2011.03.002.

Izard, C. E. (1999). Die Emotionen des Menschen. Eine Einführung in die Grundlagen der Emotionspsychologie (4th edition.) [Humans' emotions. An introduction]. Weinheim: Beltz.

Jerusalem, M., \& Mittag, W. (1999). Selbstwirksamkeit, Bezugsnormen, Leistung und Wohlbefinden in der Schule [Self-efficacy, reference-norm-orientation, achievement, and well-being in school]. In M. Jerusalem, \& R. Pekrun (Eds.), Emotion, Motivation und Leistung [Emotion, motivation, and achievement] (pp. 223-245). Göttingen: Hogrefe.

Juvonen, J. (2006). Sense of belonging, social bonds, and school functioning. In P. A. Alexander, \& P. H. Winne (Eds.), Handbook of Educational Psychology (2 ${ }^{\text {nd }}$ ed., pp. 655-673). Mahwah (N.J): Lawrence Erlbaum.

Lüftenegger, M., Schober, B., van de Schoot, R., Wagner, P., Finsterwald, M., \& Spiel, C. (2012). Lifelong learning as a goal - Do autonomy and self-regulation in school result in well prepared pupils? Learning and Instruction, 22, 27-36. http://dx.doi.org/10.1016/j.learninstruc.2011.06.001.

Muthén, L. K., \& Muthén, B. O. (1998-2009). Mplus User's Guide. $5^{\text {th }}$ Ed. Los Angeles, CA: Muthén \& Muthén.

Pekrun, R. (1992). The impact of emotions on learning and achievement: towards a theory of cognitive / motivational mediators. Applied Psychology: An International Review, 41(4), 359-376.

Pekrun, R. (1998). Schüleremotionen und ihre Förderung: Ein blinder Fleck der Unterrichtsforschung [Students' emotions and its promotion. A blind dot in instructional research]. Psychologie in Erziehung und Unterricht, 44(3), 230-248.

Pekrun, R. (2000). A social-cognitive, control-value theory of achievement emotions. In J. Heckhausen (Ed.), Motivational psychology of human development (pp. 243-163). Amsterdam: Elsevier.

Pekrun, R. (2006). The control-value theory of achievement eotions: assumptions, corollaries, and implications for educational research and practice. Educational Psychology Review, 18, 315-341. http://dx.doi.org/10.1007/s10648-006-9029-9.

Pekrun, R. (2009). Global and local perspectives on human affect. Implications of the control-value theory of achievement emotions. In M. Wosnitza, S.A. Karabenick, A. Efklides \& P. Nenninger (Eds.), Contemporary Motivation Research. From Global to Local Perspectives (pp. 97-115). Cambridge, MA; Göttingen: Hogrefe \& Huber.

Pekrun, R., Goetz, T., Frenzel, A., Barchfeld, P., \& Perry, R. P. (2011). Measuring emotions in students'learningand performance: The Achievement Emotions Questionnaire (AEQ). Contemporary Educational Psychology, 36(1), 36-48. Http://dx.doi.org/10.1016/j.cedpsych.2010.10.002.

Pekrun, R., Goetz, T., Titz, W., \& Perry, R. (2002a). Positive Emotions in Education. In E. Frydenberg (Ed.), Beyond coping: Meeting goals, visions and challenges (pp. 149-174). Oxford: Elsevier.

Pekrun, R., Goetz, T., Titz, W., \& Perry, R. (2002b). Academic emotions in students' self-regulated learning and achievement: a program of qualitative and quantitative research. Educational Psychologist, 37(2), 91-105. http://dx.doi.org/10.1207/S15326985EP3702_4.

Pekrun, R., \& Hofmann, H. (1999). Lern- und Leistungsemotionen: Erste Befunde eines Forschungsprogramms. [Learning and achievement emotions. First results of a research program]. In M. Jerusalem, \& R. Pekrun (Eds.), Emotion, Motivation und Leistung [Emotion, motivation, and achievement] (pp. 247-267). Göttingen: Hogrefe.

Plutchik, R. (1980). A general psychoevolutionary theory of emotion. In R. Plutchik, \& H. Kellerman (Eds.), Emotion: Theory, research, and experience: Vol. 1. Theories of emotion (pp. 3-33). New York: Academic.

Rauer, W., \& Schuck, K. D. (2003). Fragebogen zur Erfassung emotionaler und sozialer Schulerfahrungen von Grundschulkindern dritter und vierter Klassen (FEESS 3-4)[Questionnaire assessing emotional and social experiences of third and forth graders]. Göttingen: Beltz Deutsche Schultests.

Reisenzein, R. (2001). Appraisal processes conceptualized from a schematic-theoretic perspective. In K. R. Scherer, A. Schorr, \& T. Johnstone (Eds.), Appraisal processes in emotion (pp. 187-201). Oxford, UK: Oxford University Press.

Reschly, A. L., Huebner, E. S., Appleton, J. J., \& Antaramian, S. (2008). Engagement as flourishing: the contribution of positive emotions and coping to adolescents' engagement at school and with learning. Psychology in the Schools, 
45(5), 419-431. Http://dx.doi.org/10.1002/pits.20306.

Ryan, R. M., \& Connell, J. P. (1989). Perceived locus of causality and internalization: Examining reasons for acting in two domains. Journal of Personality and Social Psychology, 57(5), 749-761.

Scherer, K. R. (2004). Feelings integrate the central representation of appraisal-driven response organization in emotion. In A. S. R. Manstead, N. Frijda, \& A. Fischer (Eds.). Feelings and emotions: The Amsterdam symposium (pp. 136-157). Cambridge, UK: Cambridge University Press.

Schutz, P. A., \& Pekrun, R. (2007) (Eds.). Emotion in Education. Amsterdam: Elsevier.

Skinner, E. A., \& Belmont, M. J. (1993). Motivation in the classroom: Reciprocal effects of teacher behaviour and student engagement across the school year. Journal of Educational Psychology, 85(4), 571-581.

Tesser, A., \& Campbell, J. (1983). Self-definition and self-evaluation maintenance. In J. Suls, \& A. G. Greenwald (Eds.), Psychological perspectives on the self (Vol. 2, pp. 1-31). Hillsdale, NJ: Lawrence Erlbaum.

Villavicencio, F. T., \& Bernardo, A. B. (2012). Positive academic emotions moderate the relationship between self-regulation and academic achievement. British Journal of Educational Psychology, i-article first:Http://dx.doi.org/10.1111/j.2044-8279.2012.02064.x.

Watson, D., \& Tellegan, A. (1985). Toward a consensual structure of mood. Psychological Bulletin, 98, 219-235.

Wentzel, K. R. (2009). Students' relationships with teachers as motivational contexts. In K. R. Wentzel \& A Wigfield (Eds.), Handbook of Motivation at School (pp. 301-322). New York: Routledge.

Wigfield, A., \& Eccles, J. S. (1989). Test Anxiety in Elementary and Secondary School Students. Educational Psychologist, 24(2), 159-183. http://dx.doi.org/10.1207/s15326985ep2402_3.

Zelenski, J. M., \& Larsen, R. J. (2000). The distribution of basic emotions in everyday life: A state and trait perspective from experience sampling data. Journal of Research in Personality, 34(2),178-197. http://dx.doi.org/10.1006/jrpe.1999.2275.

\section{Notes}

Note 1. Lower level secondary school education is stratified in Austria. After primary school (grades 1-4) students attend either "Hauptschulen" which are low track schools or "Gymnasien" which are high track schools. "Hauptschulen" mainly prepare students for an apprenticeship after grade 9, while "Gymnasien" are more academically focused and prepare students for Universit

\section{(cc) EY}

This work is licensed under a Creative Commons Attribution 3.0 License. 